\title{
25- Bir ahenk unsuru olarak Ahmet Hamdi Tanpınar'ın şiirlerinde sözcükten sözcüğe geçişlerde seslemleme
}

\section{Caner SOLAK ${ }^{1}$}

APA: Solak, C. (2022). Bir ahenk unsuru olarak Ahmet Hamdi Tanpınar'ın şiirlerinde sözcükten sözcüğe geçişlerde seslemleme. RumeliDE Dil ve Edebiyat Araştırmaları Dergisi, (26), 431-440. DOI: $10.29000 /$ rumelide.1073953.

\section{$\ddot{O} z$}

Bu çalışmada, Ahmet Hamdi Tanpınar’ın son hâlini vermiş olduğu Şiirler adlı kitabında yer alan şiirler, yekpare şiir kavramı ve seslemleme (heceleme) vasıtasıyla oluşan ahenk bakımından değerlendirilmiştir. Geleneksel ve modern şiirde vezin ve ahenk ilişkisinin benzerlikleri ve farklılıkları üzerinde durulduktan sonra Tanpınar’ın şiir estetiğinin önemli bir unsuru olan yekpare şiirin tanımı verilmiştir. Yekpare şiiri hem anlam hem de biçim açısından bir cümleymiş izlenimi verebilen şiir olarak tanımladık. Çalışmanın kapsamı nedeniyle yekpareliğin anlamsal boyutundan ziyade ses yönü üzerinde duruldu. Şiirde müzikaliteyi inşa etmesi için tasarlanan ses ve söz düzenlemeleri dilin kendi ses uyumu kurallarından da beslenmektedir. Türkçenin ses uyumu kuralları neticesinde ünlü harfle sonlanıp ünlü harfle başlayan iki kelime art arda geldiğinde bir ahenksizlik meydana gelmektedir. Ömer Demircan'a göre Türkçede ünlüyle başlayan kelimelerin önlerinde yazıda gösterilmeyen ses tellerinin ses yolunu kapatmasıyla çıkarılan patlamalı [?] ünsüzü bulunmaktadır. Bunu sesin ağızdan çıkışı sırasında oluşan doğal bir duraksama olarak düşünebiliriz. Yekpare şiir yazma arzusunda olan bir şair için Türkçenin ses özelliklerinin meydana getirdiği okuyuş gecikmelerinin tesadüflere bırakılmayacağı ön varsayımında bulunabiliriz. Bu sebeple Tanpınar’ın Şiirler kitabında yer alan şiirlerdeki sözcükten sözcüğe geçişler, seslemleme kuralına uygun olacak şekilde devamlılıklar ve kesintiler açısından örneklerle şematize edilerek gösterildi. Yekpare ve akıcı bir şiirden yana olan şairin ünlüyle biten bir kelimeden sonra ünlüyle başlayan bir kelime kullanmaktan çoğunlukla kaçındığını tespit ettik. Şairin ender de olsa bu tarz kullanımlarının bir simetri içerisinde olması ise şiirin sesinin bölüneceği / duraklatılacağı yerlerin bilinçli olarak seçildiğini düşünmemizi sağladı.

Anahtar kelimeler: Ahmet Hamdi Tanpınar, şiir, ahenk, seslemleme

\section{Syllable as an element of harmony in the transitions from word to word in Ahmet Hamdi Tanpinar's poems}

\begin{abstract}
In this study, the poems in Ahmet Hamdi Tanpınar's book titled Poems were evaluated in terms of monolithic poetry and syllable. The similarities and differences of the relationship between measure and harmony in traditional and modern poetry are emphasized. The definition of monolithic poetry, which is an important element of Tanpmar poetry aesthetics, is given. We can define monolithic poetry as a sentence in terms of both meaning and form. In this study, the focus is on the sound dimension rather than the meaning dimension of the monolithic poem. According to the phonetic harmony rules of Turkish, the combination of two words ending with a vowel and starting with a vowel causes inconsistencies. According to Ömer Demircan, words starting with a vowel in Turkish
\end{abstract}

Dr. Öğr. Üyesi, Erzurum Teknik Üniversitesi, Edebiyat Fakültesi, Türk Dili ve Edebiyatı Bölümü (Erzurum, Türkiye), canersolak86@hotmail.com, ORCID ID: 00oo-0002-6295-6513 [Araştırma makalesi, Makale kayıt tarihi: 14.01.2022kabul tarihi: 20.02.2022; DOI: 10.29000/rumelide.1073953]

Adres | Address

RumeliDE Dil ve Edebiyat Araştırmaları Dergisi Osmanağa Mahallesi, Mürver Çiçeği Sokak, No:14/8 Kadıköy - İSTANBUL / TÜRKIYE 34714 e-posta: editor@rumelide.com

RumeliDE Journal of Language and Literature Studies Osmanağa Mahallesi, Mürver Çiçeği Sokak, No:14/8 Kadıköy - ISTANBUL / TURKEY 34714 tel: +90 $5057958124,+902167730616$

-mail: editor@rumelide.com,

phone: +90 5057958124 , +90 2167730616 
have an explosive [?] consonant produced by closing the vocal tract of the vocal cords. We can think of this situation as a natural pause that occurs when the voice comes out of the mouth. For a poet who wants to write a monolithic poem, we can guess that reading delays due to the phonetic features of Turkish cannot be left to chance. The transitions from word to word in the poems in Tanpınar's book of Poems were examined in terms of continuity and interruptions in accordance with the syllable rule. The fact that such uses of the poet are in a symmetry has led us to think that the places where the voice of the poem will be cut off are deliberately chosen.

Keywords: Ahmet Hamdi Tanpınar, poem, sarmony, syllable

\section{Giriş}

Şiirde ünlü ve ünsüz harflerin uyumlu ve düzenli bir şekilde kullanımı asonans ve aliterasyon sanatlarını doğurur. Bununla birlikte şiir içerisinde hece, hece kümeleri ve kelimelerin -serbestçe- tekrarı da bir armoni unsurudur. Hatta modern şiir dinlenilmek için olduğu kadar okunmak ve bakılmak için de yazılabildiğinden tekrar eden görsel bloklardan dahi bir armoni unsuru olarak bahsedebiliriz. Şiirde tekrar eden hem görsel hem de sessel bakımdan uyumlu yapıları simetrik ve asimetrik olanlar şeklinde sinıflandırabiliriz.

Şiirde ahenk için dilin yarattığı musiki denilebilir. Şiiri oluşturan kelimelerin okuyucuda anlamsal olduğu kadar sessel karşılıkları da bulunmaktadır. Güzelin peşinde koşan şair için ne söylediği kadar nasıl söylediği de önemli olduğundan şiirin temel yapı malzemesi olan kelimelerin gerek tek başlarına gerekse bir bütün dâhilinde meydana getirdikleri sesin uyumu / ahengi çok önemlidir. Tunca Kortantamer bu konuda, "Ses düzenlemeleri, anlam yapısıyla ilintileri oranında estetik çekiciliklerinin alanını genişletirler. Bu bakımdan iyi bir şiirde (...) kişiler, nesneler, zaman ve mekân dünyasını biçimlendiren ses ve söz düzenlemelerinin bütünü, aynı zamanda şiirin genel havasını oluştururlar. Burada artık şiirin bütününü kavrayan bir sesten söz edilebilir." demektedir (Kortantamer, 1993, s. 278279). Bir şiiri meydana getiren unsurlar ses ve söz düzenlemeleri bakımından incelenmek istendiğinde öncelikle, şiire doğal olarak ahenk katan vezin, kafiye, redif ve diğer belagat kaideleri aranır. Ancak inceleme nesnemiz, şiirde müzikaliteyi inşa ederken bilinçli olarak bu unsurlardan uzak duran modern şiir olduğunda daha farklı bir yaklaşım geliştirmemiz gerekir. Serbest şiirin gelenekle kurduğu ikircikli ilişkinin kendisine kazandırdıklarını Ali Nihat Tarlan; "Serbest nazım, mevzua en uygun âhenk ve âhensizliğin birleştiği noktadır. Telleri ipten bir mûsıkî aletiyle, terennüm etmeye benzer. O ip, telli saza, kendi bir ânının âhengini vermeye mecburdu. Serbest nazım, lirizmin muntazam tekniğini kırıp hem zaman, hem de mâhiyet itibariyle ilerlemiş bir şekildir." ifadeleriyle belirtir (Tarlan, 1981, s. 39). Tarlan'ın serbest şiir hakkında oldukça yerinde olan tespitlerinden yola çıtığımızda modern şiirde ahenk mevzusunu araştırırken şairin bilinçli olarak oluşturduğu ahenkle o ahengi yine kendi eliyle sekteye uğrattı̆̆ı yerleri içerik-biçim uyumu çerçevesinde değerlendirmemiz gerektiğini söyleyebiliriz.

Bu çalışmada, Ahmet Hamdi Tanpınar'ın son hâlini vermiş olduğu Şïrler adlı kitabında yer alan şiirler yekpare şiir kavramı ve seslemleme (uzunluk ekleme) bakımından değerlendirilecektir.

Tanpınar'a göre şiir en başta bir şekil meselesidir. "Şekle inanıyorum, çünkü kurduğu zarûretler ve getirdiği zorluklarla o, bana, kendimi tahakkuk ettirmek imkânını veriyor. Onu ararken kendimi buluyorum. O beni ayıklıyor, temizliyor ve derinleştiriyor. $\mathrm{O}$, benim hareket sahamdır, bu üç veya dört kıta içinde ben, muharebelerimi veriyor, zaferlerimi kazanıyor ve ricatlerimi idâre ediyorum. Ve her defasında çok esaslı bir şeyi, bir oyuna riâyet etmeyi öğreniyorum. Sözümü başkalarının sözünden ve

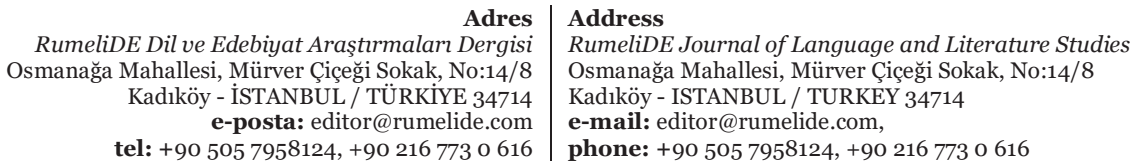


sükûtumu başkalarının sükûtundan ayıran odur." (Tanpınar, 2005, s. 26). Şiirlerinin büyük çoğunluğunu hece vezniyle yazmış olan Tanpınar için veznin bu sebeple ayrı bir önemi vardır. "Bir veznin etrafında başlayan o ilk mısra, onun içimizde kımıldanışı, o veznin, yani sesin birden size ait bir 'rytme' oluşu, onu benimseyerek emrine girmeniz. Kafiyelerin tuttuğu ışıkta, onların uyandırdığı dikkatle adım adım yürüyüşünüz... Birden dilin içine düşersiniz. Her kelimeyi ayrı ayrı bulmak, ayırmak, bir biri ile kaynaştırmak lâzımdır. Yavaş yavaş kıtalar veya büyük ritm cümleleri başlar... Bu başlama, bu yürüyüş, bu bitişte şiirin sırrı teşekkül eder." (Tanpınar, 1996, s. 316). Tanpınar'ın belirttiği üzere vezin şaire -gelenek içinde kaldığı sürece- hazır bir ritim ve ses sunmaktadır. Modern şaire düşen geleneğin kendisine hazır sunduğu vezni ve onun şiire sağlamış olduğu müzikaliteyi kendisine ait kılmaktadır. Dolayısıyla öncelikle Tanpınar’ın hece vezni üzerindeki tasarruflarını araştırmalıyız.

Mehmet Kaplan, Tanpınar’n Şür Dünyası adlı kitabında "Bu şiirin (halk şiiri) vezin ve şeklini benimseyen aydın şairler, muhtevasını değiştirmekle beraber monoton yapısını fazla kıramamışlardır. Tanpınar'ın hece vezninde yaptığı en mühim değişikliklerden biri, çeşitli gramatikal oyunlarla onu bu monotonluktan kurtarmak olmuştur." demektedir (Kaplan, 2013, s. 172). Mehmet Kaplan'in Tanpınar'ın Şïrler kitabında tespit ettiği gramatikal oyunlardan bazıları; tek başına bir ünite teşkil eden tablo-mısralar, tahlili mısralar, yekpare mısralar, iki mısralık gruplar, tek bir cümle teşkil eden dörtlüklerdir (Kaplan, 2013, s. 168-172). Bu oyunların temel amacı gerek tek mısrada gerekse dize veya kıta hâlinde içerik ve şekil bakımından bütünleşmiş, yekpare yapılar meydana getirmektir. "Tanpınar'ın da özlediği, hece vezni içinde Valéry ve Mallermé tarzında bir şiir cümlesi yaratmaktı." (Kaplan, 2013, s. 174). Yekparelikten kasit, şiirin hem anlam hem de biçim açısından bir cümleye dönüşebilmesidir. Yekpareliğin anlam², ses uyumu ve bütünlüğünden oluştuğunu kabul ettikten sonra şiirin tamamına hâkim olan ya da olduğu söylenen bir sesten ve o sesin unsurlarından bahsedebiliriz. Şiirin müzikal yönü; şairin sanatçı dehası ile yoğun şiir işçiliğinin bir ürünü olarak Türkçenin de imkânlarından faydalanılarak ortaya çıkarılır. Şiirde müzikaliteyi inşa etmesi için tasarlanan ses ve söz düzenlemeleri dilin kendi ses uyumu kurallarından beslenmekle birlikte okuyucu da şiirin ideal okunuşunu gerçekleştirmesi için çeşitli vasıtalar aracllı̆̆ıla yönlendirilir. Bunun için noktalama işaretlerinden faydalanılabileceği gibi Tanpınar'ın şiir anlayışına bağlı olarak kendi içinde hiç bölünmeyen bir şiir (okuma) için birbirinden ayrılabilen ve ayrılamayan kelime gruplarından, tamlamalardan ve tekrarlardan faydalanılır. Okuma hızının ve süresinin okuyucunun nefes süresiyle alakası olduğu söylenilebilir. Mısraların hem şekil yapısı hem de hece sayısına bağlı olarak uzunlukları, okuyucunun göz hareketleri ile nefes süresinin hesaba katılması sonucunda meydana getirilir. Serbest şiirde şair, dizeleri okumayı yönlendirecek şekilde kurabilirken, her mısradaki hece uzunluklarının eşitliğine dayanan hece veznini kullanan geleneğe bağlı şair, durak ve vurgulardan bu anlamda daha fazla istifade etmektedir. Peki, bu durumda geleneksel şekilleri kullanan modern şair için vezin ne anlama gelmektedir?

\section{Yekpare Şiir Duraksız Şiir midir?}

Cem Dilçin, Örneklerle Türk Şiir Bilgisi adlı eserinde durak için; "Takti'de sözcükler ortalarından bölünebildiği hâlde, hece ölçüsünde sözcükler bölünerek durak yapılamaz. Durak, ancak, kulakta uyumlu bir izlenim bırakan anlamlı söz öbekleri arasında olur.” der (Dilçin, 1983, s. 40). Halk şiirinde hece vezninin duraklarının kelimeleri ve anlamlı kelime gruplarını divan şiirinde olduğu gibi

“(...) ses düzenlemelerinin şiir sanatı açısından değeri, onların anlamla bağlarına göre yükselir. Şiirin anlamla bağları en zayıf olan ses düzenleme tekniklerinden birisi vezinlerdir.” (Kortantamer, 1993, s. 326)., "...duraklar tümcenin bilgi yapısından bağımsız belirlenemez.” (Demircan, 2015, s. 162) Tüm bu ifadelerin haklılığıyla birlikte bu çalıșmada Tanpınar'ın şiirlerinde seslemleme bakımından kelimeler arasındaki devamlılıklar ve kesintiler üzerine yoğunlaşılacağı için yekpareliğin anlam ayağı bilinçli olarak göz ardı edilecektir.

Adres $\mid$ Address

RumeliDE Dil ve Edebiyat Araşttrmaları Dergisi Osmanağa Mahallesi, Mürver Çiçeği Sokak, No:14/8 Kadıköy - İSTANBUL / TÜRKIYE 34714 e-posta: editor@rumelide.com

RumeliDE Journal of Language and Literature Studies

Osmanağa Mahallesi, Mürver Çiçeği Sokak, No:14/8

Kadıköy - ISTANBUL / TURKEY 34714

phone: +90 $5057958124,+902167730616$ 
bölemeyeceği anlayışı hâkim olmakla birlikte "Zannımızca hiçbir halk şairi de şiirini duraklarken 'kelime bölmemeye gayret edeyim’ gibi bir zahmet içine girmez.” şeklinde farklı görüşler de3 mevcuttur (Başaran, 2013, s. 113). Bu yoruma göre divan şiirinde takti ne ise halk şiirinde durak da odur. "Duraklar, şairin / okuyucunun şiiri belirli bir ritme göre icra etmesine / okumasına yardımcı olur. Bu yardımlar sayesinde kârî, icrası esnasında nefes alma sıklı̆̆ını ayarlar. Şairin / okuyucunun ilk baştan zihninin altına bu okuma ritmini yerleştirmesi demek, şairin / okuyucunun / icracının şiiri okurken zorlanmaması demektir. Şiirde farklı durak sistemlerinin bulunması demek, bu ritmin sekteye uğraması demek olacağından, şair şiirinin okuma ritmini değiştirmek istemeyecektir.” (Başaran, 2013, s. 113). Modern şiirde ise bu anlayıştan farklı olarak anlama göre ritimde değişiklikler yapılır ya da akıcılı̆̆ın yarattığı yeknesaklıktan kurtulmak adına ritim 4 bilinçli olarak bozulur.

Demek ki hece ölçüsüyle yazılmış modern şiirlerde duraklar geleneksel kullanımına uymayacak şekilde olabileceği gibi hiç de kullanılmayabilir. Oktay Yivli, “Ahmet Muhip Dıranas’ın Şiirinde Biçim Denemeleri” adlı makalesinde "Ahmet Muhip, geleneksel hece kalıplarını duraksız kullanarak ve gelenekte kullanılmayan hece kalıplarını yeğleyerek hece şiirine yenilikler getirmiştir.” Der (Yivli, 2011, 137-147). Tanpınar’ın yekpare şiir arzusunun yansımasını “Dönüş” şiirinde yer alan

"Birdenbire sanki çıplak (1)

Bir oynuyla hâfizanın. (2)

Bir kuş sesi çırpınarak (3)

Düştü bağrına hazanın.” (4)

mısralarında görmek mümkündür. Kıta rahatlıkla iki parça hâlinde duraksız okunmaktadır. Kıtayı ve okumayı ikiye bölen 2. mısranın sonundaki nokta işareti olmaktadır. İlk bakışta mısra uzunluklarının kısa olduğu bu şiirde okuma hızının yüksek olduğu tahmin edilmektedir. Kıta rahatlıkla iki dizeye dönüşebilmektedir. Şiirin ilk kıtası kesilmeden yazıldı̆̆ında

"Birdenbire sanki çıplak bir oynuyla hâfizanın. (1)

Bir kuş sesi çırpınarak düştü bağrına hazanın.” (2)

şekline dönüşecektir. Bu tekniğin şiire katkısı, okuma hızını arttırmasıdır. Şiirin asıl hâlinin mısra uzunluklarının daha kısa olduğu görülecektir. Ayrıca mısraların kırılması, anlamın ve okuyuşunda yarım kalmasını sağlamaktadır. Yarım kalan okuma ve anlam ise okuyucu tarafından çoğu zaman istemsiz bir şekilde alt mısraya geçilerek tamamlanmaktadır. Şiirin bu şekilde sürüp gitmesi hâlinde okuyucu içgüdüsel olarak sürekli bir alt mısraya geçmektedir. Burada ortak fiil kullanımı ve mısraların hece sayılarının kısa tutulması ayrıca önemlidir.

$\mathrm{Bu}$ durumu açıklarken Türkçenin ses özellikleri üzerine yapılan araştırmalardan faydalanabiliriz. “Türkçede Ses Sürelerine Etki Eden Etmenler ve Etkileri” adlı çalışmada hece sayısı ve sözcük sayısının ses süresi üzerindeki etkileri; "Hece sayısı: Söylenen sesle içinde bulunduğu sözcüğün hece sayısı arasındaki ilişkiye bakıldığında hece sayısı arttıkça söylenen sesin ortalama süresinin düştüğü görüldü. Sözcük sayısı: Okunan tümcedeki sözcük sayısı arttıkça, tümce içinde geçen seslerin süreleri düşmekte.” şeklinde açıklanmaktadır (Şayli, 2003, s. 16). Kısa kelime ve kısa cümleleri aslında daha uzun sürede

\footnotetext{
3 "Birçok halk edebiyatçısının kabul ettiği 'duraklar gösterilirken kelime bütünlüğü bozulmaz', 'kelimeler hecelerinden bölünmezler', 'şiirler duraklanırken herhangi bir tamlamada, tamlayan ile tamlanan arasına durak konulmaz' vs. gibi düsüncelerin sorgulanabileceğini / sorgulanması gerektiğini belirtmek istiyoruz." (Bașaran, 2013, s. 113).

"Ses, hece, biçim, görüntü, renk gibi ögelerin art arda düzenli olarak diziliși ritmi olușturur. Şiirde ritmden söz edilirken, hecelerin belli bir düzen içinde ve belli sayıda vurgulu vurgusuz, uzun kısa olarak dizilişi kastedilir.” (Şimşek, 2006, 145146). Şiirde ritm konusunda detaylı bilgi için bkz: (Can, 2015, s. 1-110).

Adres Address

RumeliDE Dil ve Edebiyat Araştırmaları Dergisi Osmanağa Mahallesi, Mürver Çiçeği Sokak, No:14/8 Kadıköy - İSTANBUL / TÜRKIYE 34714 e-posta: editor@rumelide.com

RumeliDE Journal of Language and Literature Studies

Osmanağa Mahallesi, Mürver Çiçeği Sokak, No:14/8

Kadıköy - ISTANBUL / TURKEY 34714

ail: editor@rumelide.com,

phone: +90 505 7958124, +902167730616
} 
söylediğimiz iddia edilmektedir. "Cümledeki kelime sayısı artarsa, seslerin toplam süresi artmaz. Cümlelerin payına düşen nefes eşittir. Cümledeki kelime sayısı artınca, tek tek her sese düşen nefes süresi azalır. Yani cümledeki kelime sayısı arttıkça sesin toplam süresini paylaşan seslere düşen süre de düşer." (Şayli, 2003, s. 16). Kısa kelimeler ve kısa mısralardan oluşan şiirlerin okuma hızı demek ki daha yavaş olacaktır. Bu sebeple Tanpınar, "Dönüş" şiirinin tamamında keserek yazma tekniğinden faydalanmış, kısa dizelerden mürettep dört kıtalık bu şiiri uzun dizelerden oluşan dört dize şeklinde okuması için okuyucuyu yönlendirmiştir.

Şiirde durak terimini, okuma ya da söyleme esnasında durma / susma yeri olarak tanımladığımızda modern şiirde şairlerin yeni bir ses ortaya koyabilmek için geleneksel durak noktalarının $(4+4,5+3 \cdots$ gibi) yerlerini değiştirdiklerini görürüz. Mısraları bütün hâlinde okunacak şekilde tasarlayıp durakları mısra sonlarına koymalarının duraksız şiir yazdıkları izlenimini verdiğini söyleyebiliriz. İsmail Habib Sevük "...hecede durguyu hissettirmek veznin ahengini meydana çlkarır." tespitinde bulunmuştur. (Sevïk, 1942, s. 203).

Ahmet Talât Onay, "Millî vezinle yazılmış mevzun bir parçayı durgulara ayırırken her parçanın sonuna gelen hece küçük hece olursa veznin âhengi bozulmaktadır. Bu bir kat'î kaide değildir." der (Onay, 1996, s. 33). Bu durumda hece vezninde kesin bir kaide olmamakla birlikte ünlü ile biten kelimelerin ahengi bozdukları söylenilebilir. Türkçede vurgu çoğunlukla kelime sonlarında yer almaktadır, ayrıca "be-bekan-ne-sin-de-nay-rı tümcesinde olduğu gibi her seslem 5 bir ünsüzle başlayacak biçimde seslemlere bölünmektedir." (Demircan, 1981, 41). Dolayısıyla ünlü harfle sonlanıp ünlü harfle başlayan iki kelime art arda geldiğinde bir ahenksizlik meydana gelmektedir. Ömer Demircan’a göre Türkçede ünlüyle başlayan kelimelerin önlerinde yazıda gösterilmeyen ses tellerinin ses yolunu kapatmasıyla çıkarılan patlamalı [?] ünsüzü bulunmaktadır. "Ses tellerinin bitişerek ses yolunu bir an için kapatıp sonra birden açmalarıyla çıkarılan [?] sesi, tıpkı p t k... gibi 'ötümsüz, patlamalı’ bir ünsüzdür. Onlardan yalnızca çıkış yeri bakımından ayrılmaktadır.” (Demircan, 1981, 41). [?] ünsüzü ile ötümsüz patlamalı sesler arasındaki benzerliğin bizim için önemli yanı bu seslerin çıkarılmasında doğal bir durum olarak ortaya çıkan gecikmedir. Bunu sesin ağızdan çıkışı sırasında oluşan doğal bir duraksama olarak düşünebiliriz. Yekpare şiir yazma arzusunda olan bir şair için Türkçenin ses özelliklerinin meydana getirdiği okuyuş gecikmelerinin tesadüflere bırakılmayacağı ön varsayımında bulunabiliriz.

Bu ünsüzün varlığından ötürü 'oğ-lu-na a-ra-ba al-dı' şeklinde hecelenen bu cümle yavaş okunduğunda '? oğ-lu-na-? a-ra-ba-? al-dı', hızlı okunduğunda ise '?oğ-lu-nă̆-ra-bağl-dı' şeklinde seslendirilmektedir. Vezinlerdeki ulamayı da ara ünlülerin doğal olarak ünsüzle başlatılması olarak yorumlayabiliriz. Bu durum dilin ses özellikleriyle ilgilidir. İki ünlünün art arda gelmesi durumunda doğal olarak oluşan (sa'at, araba aldı) duraklardan, ses bölünmelerinden bahsedebiliriz (Demircan, 1981, s. 41, 46; Demircan, 2015, s. ?).

\section{Şiirler kitabında seslemleme örnekleri}

Bu bilgiler ışığında Tanpınar'ın Sabah (şema 1) şiirindeki durak noktaları, kelimelerin ünlü ve ünsüz harfle başlaması ve bitmesi durumlarına dikkat edilerek şematize edildiğinde,

\footnotetext{
5 Ömer Demircan seslem’i hece, seslemlemeyi ise heceleme yerine kullanmıştır. (Demircan, 1981, s. 40). Adres | Address 
436 / RumeliDE Journal of Language and Literature Studies 2022.26 (February)

Syllable as an element of harmony in the transitions from word to word in Ahmet Hamdi Tanpınar's poems / C. Solak (pp. 431440)

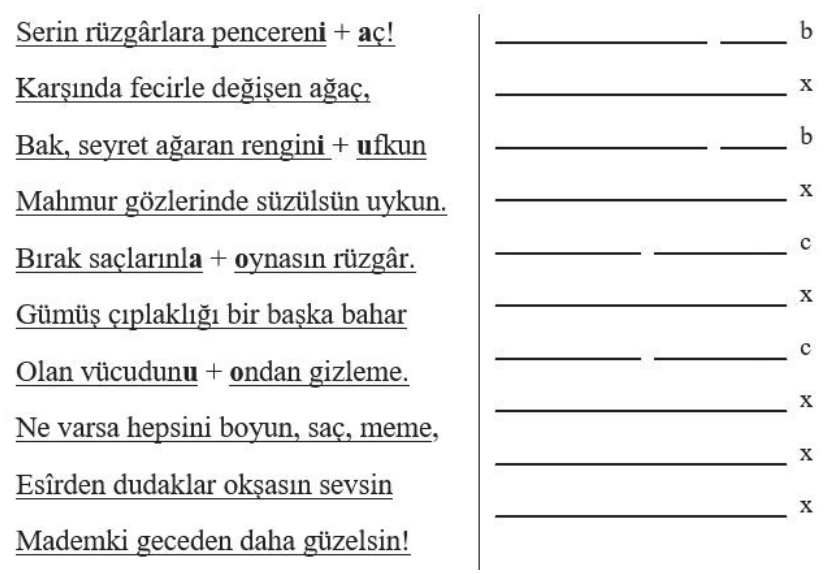

Şema 1: "Sabah" şiiri

şeklinde bir yapıyla karşılaşırız. Yekpare ve akıı bir şiirden yana olan şairin ünlüyle biten bir kelimeden sonra ünlüyle başlayan bir kelime kullanmaktan kaçındığını söyleyebiliriz (bu durumu tüm şiir kitabı için genelleyebiliriz). Şairin ender de olsa bu tarz kullanımlarının bir simetri içerisinde olması ise şiirin sesinin bölüneceği / duraklatılacağı yerlerin bilinçli olarak seçildiğini düşünmemizi sağlar.

"Yollar Çok Erken" (şema 2) ve "Bursa'da Zaman" (şema 3) şiirinin son bendinde ünlüyle biten bir kelimeden sonra ünlüyle başlayan bir kelimenin geldiği ve gelmediği durumların simetrik bir şekilde kullanıldığını söyleyebiliriz.

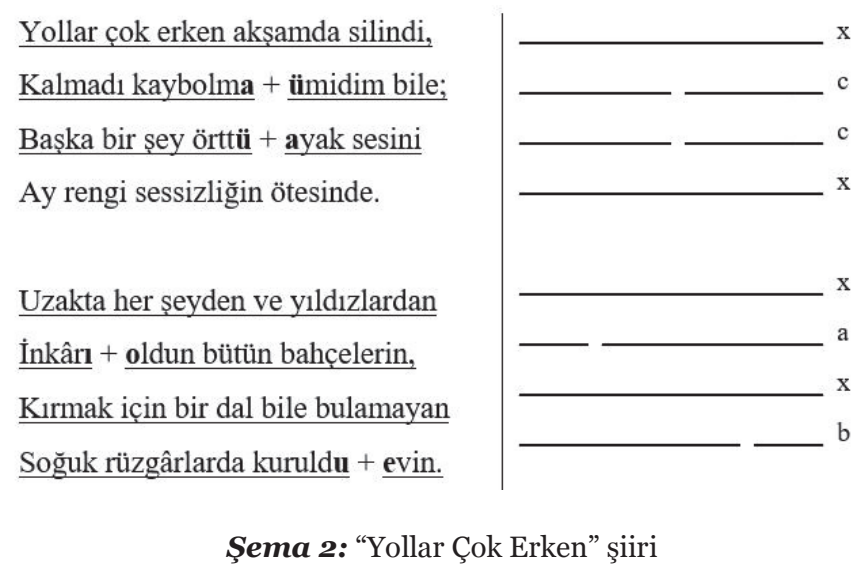

\footnotetext{
Adres | Address

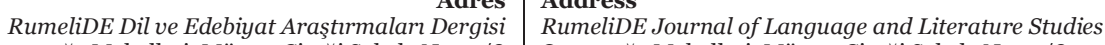

Osmanağa Mahallesi, Mürver Çiçeği Sokak, No:14/8 $\quad$ Osmanağa Mahallesi, Mürver Çiçeği Sokak, No:14/8

Kadıköy - İSTANBUL / TÜRKIYE 34714 Kadıköy - ISTANBUL / TURKEY 34714

e-posta: editor@rumelide.com e-mail: editor@rumelide.com,

phone: +90 5057958124, +90 2167730616
} 


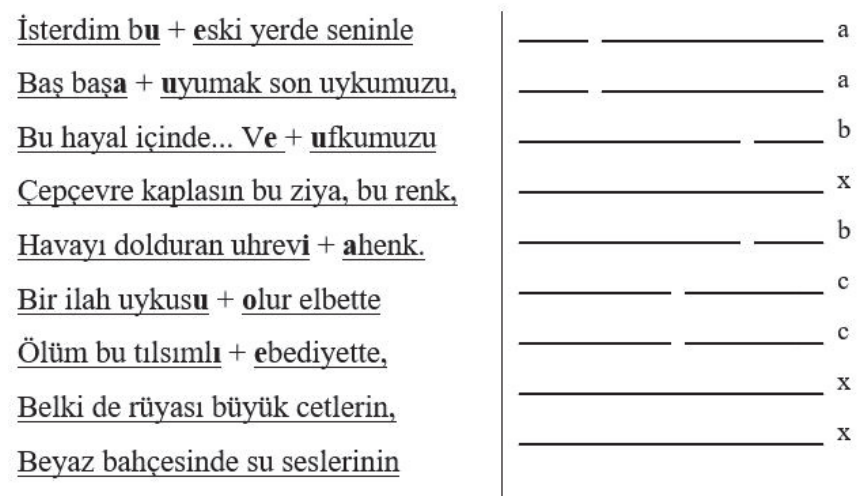

Şema 3: "Bursa'da Zaman” şiiri

Farklı şiirlerde ses devamlılıklarının ve kesintilerinin benzer şekilde kullanıldı̆̆ını görürüz. "Ey Kartal Bakışlı" ve "Hatırlama" (şema 4) şiirleri ile "Rıhtımda Uyuyan Gemi”" ve "Mavi Maviydi Gökyüzü" (şema 5) şiirleri bu benzer kullanıma örnektirler.

\begin{tabular}{|c|c|c|}
\hline Ömrün gecesinde sükûn, aydınlık & Ey solgun mabude, kadehlerimiz & \\
\hline Boșanan bir seldi + avuçlarından, & 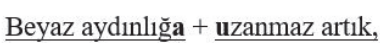 & \\
\hline Bir masal meyvası gibi paylaștık & Aynalar kırıldı mevsimlerle, biz & \\
\hline Mehtabı kırılmıș dal uçlarından. & Surrın gecesinde rüyaya daldık. & - \\
\hline
\end{tabular}

Şema 4: "Ey Kartal Bakışlı" ve "Hatırlama” şiirleri

Yırtılan yelkenler gibi
Enginle baș bașa kalsak
Ve bir șafak serinliği
$\underline{\text { İcinde }+ \text { uykuya dalsak. }}$

$\mid \begin{aligned} & \text { Beyaz, beyazdı bulutlar, } \\ & \text { Gölgeler buğulu, derin; } \\ & \underline{\text { Ah o hiç dinmeyen rüzgâr }} \\ & \underline{\text { Ve }+ \text { uykusu ciçeklerin. }}\end{aligned}$

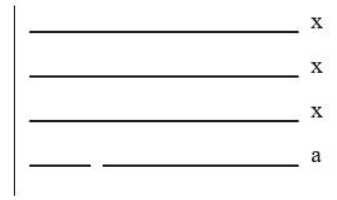

Şema 5: "Rıhtımda Uyuyan Gemi” ve “Mavi Maviydi Gökyüzü” şiirleri

"Raks" (şema 6), "Yollar Çok Erken” (şema 7) ve "Her Şey Yerli Yerinde" (şema 8) şiirlerinde kelime başlangıç ve sonlarında ünlü kullanımlarını şematize ettiğimizde birbirinin ters simetriği olan yapılarla karşllaşırız. Şiirler tam ortadan ikiye ayrılabildikleri gibi bölünen parçalar birbirlerinin üstüne kapanacak şekilde simetrik olurlar. Kaya Bilgegil'e göre "Bir cümle veyâ mısrầın sondaki kısmını başa almak, baştaki kısmını sona getirmek sûretiyle diğer bir cümle veyâ mısrâ’ teşkîl etmek, akis sanatını meydâna getirir.” (Bilgegil, 1980, s. 331). "Raks" (şema 6), şiiri seslemleme bakımından iki ters simetrik parçaya bölünebilir. İlk bloğun sondan bir önceki mısra ile ikinci bloğundan baştan bir sonraki mısraı özdeştir. "Yollar Çok Erken" (şema 7) şiirinde kıtanın birinci ve dördüncü mısraları birbiri üzerine kapanırken, "Her Şey Yerli Yerinde” (şema 8) şiirinde ikinci ve üçüncü mısraların özdeş olduklarını görürüz. Bu şiirlerde kullanılan benzer seslemleme şekillerinin akis sanatının mısra boyutunda farklı bir kullanımı olduğu söylenilebilir.

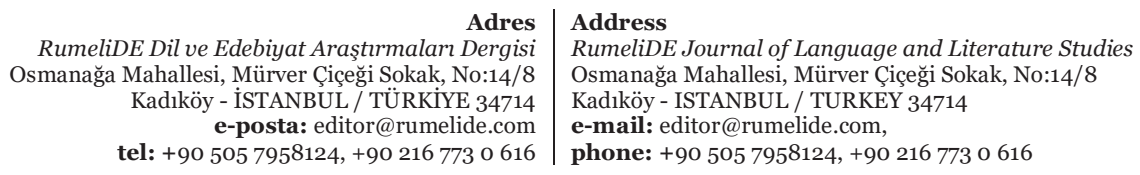


438 / RumeliDE Journal of Language and Literature Studies 2022.26 (February)

Syllable as an element of harmony in the transitions from word to word in Ahmet Hamdi Tanpınar's poems / C. Solak (pp. 431440)

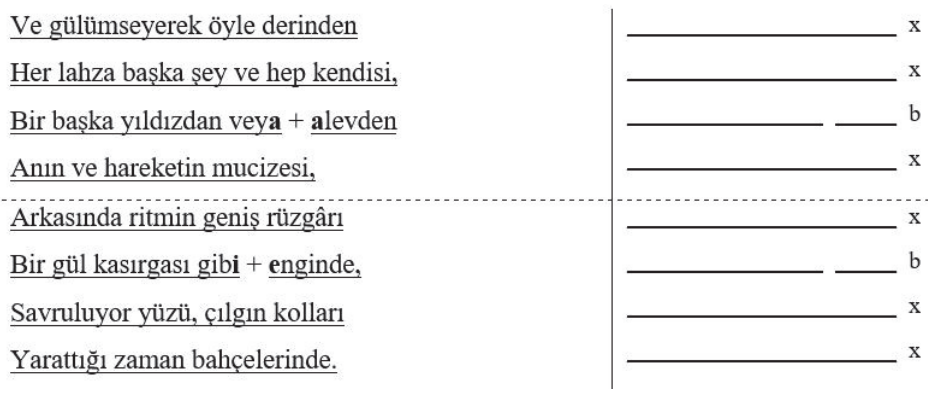

Şema 6: "Raks" şiiri

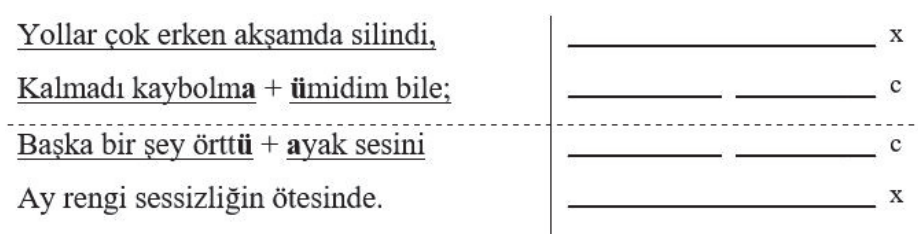

Şema 7: "Yollar Çok Erken" şiiri

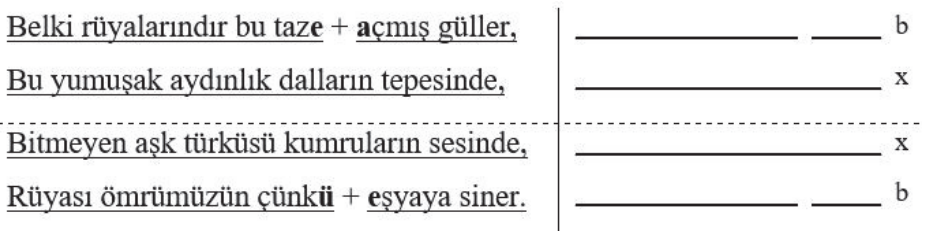

Şema 8: "Her Şey Yerli Yerinde” şiiri

Şimdiye kadar yapmış olduğumuz alıntılardan görüldüğü üzere şair, şiirinde sözcükten sözcüğe geçişlerde, ünlü kullanımında ya da kullanılmamasında bilinçli ya da bilinçsiz olarak simetrik yapılar meydana getirmiştir. Bu düzenli devamlllkklar veyahut kesintiler ise yekpare ahengi var eden birçok unsurdan yalnızca biri olmuşlardır.

\section{Sonuç}

İsmail Habib Sevük, hece vezni için "Aruzda hem «kemiyet», hem «keyfiyet» mutabakati vardı. Hecede yalnız «kemiyet»e, yani hece adedine bakılır.” der (Sevük, 1942, s. 202). Tanpınar ise hece vezniyle yazdığı şiirlerinde kelime seçiminde hem anlam hem de ses açısından uyuma büyük önem veren bir şairdir.

Tanpınar'ın en son hâllerini verdikten sonra yayımladığı otuz yedi şiirinin yer aldığı Şïrler kitabındaki şiirlerin hece ve mısra uzunlukları bakımından dökümünü yaptığımızda şöyle bir tabloyla karşılaşırız:

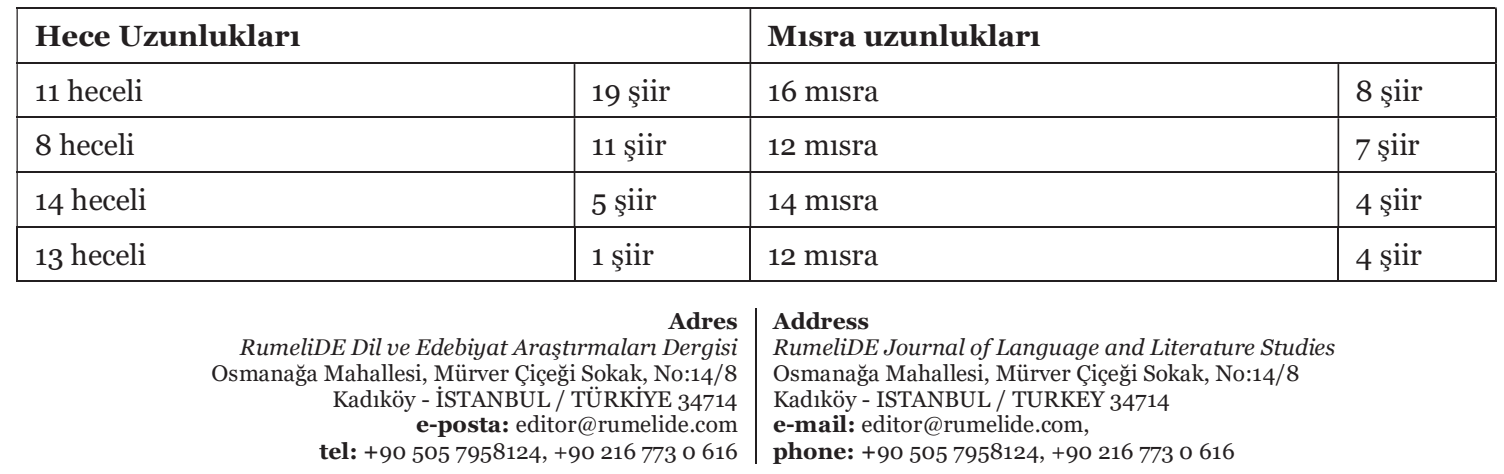




\begin{tabular}{|c|c|c|c|}
\hline 9 heceli & 1 şiir & 24 misra & 3 şiir \\
\hline & & $20 \mathrm{misra}$ & 2 şiir \\
\hline & & 7 misra & 2 şiir \\
\hline & & 6 misra & 2 şiir \\
\hline & & 44 misra & 1 şiir \\
\hline & & $40 \mathrm{misra}$ & 1 şiir \\
\hline & & 11 misra & 1 şiir \\
\hline & & 10 misra & 1 şiir \\
\hline & & 4 misra & 1 şiir \\
\hline Ortalama hece uzunluğu & 10,51 & Ortalama misra uzunluğu & 15,21 \\
\hline
\end{tabular}

Tablo 1: Ahmet Hamdi Tanpınar'ın Şïrler kitabında yer alan şiirlerin hece ve mısra uzunlukları

Tanpınar’ın şiirlerinin kâğıt üzerinde dikey ve yatay düzlemlerde ne kadar yer kapladığını gösteren bu tablo aracılığı ile şairin ağırlıklı olarak 11 ve 8 heceli mısralar kurduğunu, ortalama olarak 3-4 kıtalık 1216 mısra uzunluğunda şiirler yazdığını görürüz. Bu durum şairin şiirlerini yatay ve dikey düzlemde ne kadar yer kaplayacağını hesap ederek yazdığını gösterir. Eserleri yoğun bir işçiliğin ürünü olan Tanpınar'ın Şïrler kitabında oluşturmak istediği 'ortalama şiir’in dış hatlarını (kalıbını) bu şekilde ortaya koyabiliriz. Bundan çok daha zor olan ise Tanpınar’ın üslubunun ses ayağını ortaya çıkarmak için yapılacak çalışmada şairin önce ortalama sesini, sonra bu sesin her şiirde nasıl tekrardan farklı farklı yollarla inşa edildiğini araştırmaktır. Bu çalışmada Türkçenin ses özelliklerinin araştırıldığı dilbilim çalışmalarında, üzerinde durulan bir kavram olan seslemlemeden faydalanılarak şairin ahenk oluştururken kullanmış olduğu enstrümanlardan şimdiye kadar çok üzerinde durulmamış olan biri üzerine dikkat çekilmeye çalışılmıştır.

\section{Kaynakça}

Başaran, U. (2013). Durak terimini yeniden tartışmak. Bilim ve Kültür - Uluslararası Kültür Araştırmaları Dergisi. (2), 108-114.

Bilgegil, K. (1980). Edebiyat bilgi ve teorileri. Atatürk Üniversitesi Yayınları.

Can, A. (2015). Şïr /de/ ritim. Birleşik Dağıtım Kitabevi.

Demircan, Ö. (1981). Türkiye Türkçesinde seslemleme. Dilbilim. 39-54.

Demircan, Ö. (2002). Türkçenin ses dizimi. Der.

Dilçin, C. (1983). Örneklerle Türk şïr bilgisi. TDK.

Kaplan, M. (2013). Tanpınar’in şïr dünyası. Dergâh.

Kortantamer, T. (1993). Türk şiirinde ses konusunda ve ses gelişmesinin devamlılı̆̆ı üzerine genel bazı düşünceler I. Eski Türk edebiyatı-makaleler, Akçağ, 273-336.

Onay, A. T. (1996). Türk şürlerinin vezni. (Haz.) Cemal Kurnaz. Akçağ.

Sevük, İ. H. (1942). Edebiyat bilgileri. Remzi Kitabevi.

Şayli, Ö., Arslan, L. M., Özsoy, A. S. (2003). Türkçe'de ses sürelerine etki eden etmenler ve etkileri. XVII. Dilbilim Kurultayı, Anadolu Üniversitesi Eskişehir 22-23 Mayı 2003. https://silo.tips/download/no-title-16303

Şimşek T. (2006). Türk şiirinde ses ve ritm konusuna yeni bir yaklaşım. Atatürk Üniversitesi Türkiyat Araştırmaları Enstitüsü Dergisi. (29), 145-168.

Tanpınar, A.H. (2005). Edebiyat üzerine makaleler. (Haz.) Zeynep Kerman. Dergâh.

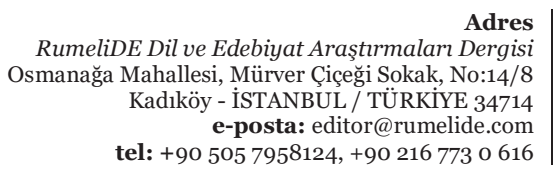

Adres

/8

Eournal of Language and Literature Studies

Osmanağa Mahallesi, Mürver Çiçeği Sokak, No:14/8

Kadıköy - ISTANBUL / TURKEY 34714

e-mail: editor@rumelide.com

phone: +90 $5057958124,+90216773$ o 616 
440 / RumeliDE Journal of Language and Literature Studies 2022.26 (February)

Syllable as an element of harmony in the transitions from word to word in Ahmet Hamdi Tanpınar's poems / C. Solak (pp. 431440)

Tanpınar, A. H. (1996). Yaşadığım gibi. (Haz.) Birol Emil. Dergâh.

Tarlan, A. N. (1981). Edebiyat meseleleri. Ötüken.

Yivli, O. (2011). Ahmet Muhip Dıranas’ın şiirinde biçim denemeleri. Ankara Üniversitesi Dil ve TarihCoğrafya Fakültesi Türkoloji Dergisi. 18(2), 137-147.

RumeliDE Dil ve Edebiyat Araşttrmaları Dergisi Osmanağa Mahallesi, Mürver Çiçeği Sokak, No:14/8 Kadıköy - İSTANBUL / TÜRKIYE 34714 tel: +90 5057958124,+90 216773 o 616
Address

RumeliDE Journal of Language and Literature Studies

Osmanağa Mahallesi, Mürver Çiçeği Sokak, No:14/8

Kadıköy - ISTANBUL / TURKEY 34714

e-mail: editor@rumelide.com

phone: +90 5057958124, +90 2167730616 